\title{
Large ranches as conservation tools in the Venezuelan Ilanos
}

\author{
Rafael Hoogesteijn and Colin A. Chapman
}

Traditionally, wildlife conservation efforts have concentrated on the establishment of national parks and reserves. Additional strategies are needed if we are to conserve more than a small proportion of the world's natural habitats and their wildlife. One such strategy is the application of wildlife conservation regulations by private land owners on their properties. This paper uses examples of ranches in the seasonally flooded llanos of Venezuela to evaluate if effective wildlife conservation can coexist with sustainable wildlife use and cattle production. Income estimates derived from cattle production data varied among ranches from \$US7.1 to \$US26.4 per ha, while estimates of potential additional income through regulated capybara Hydrochaeris hydrochaeris and caiman Caiman crocodilus exploitation ranged up to \$US7.7 per ha. The economic benefits of capybara and caiman harvests can be realized only by protecting wildlife habitat. Thus, it is suggested that large ranches in the llanos can play a major role in wildlife conservation as well as provide economic gains for those involved. Common denominators for success are: personal involvement of owners, effective patrolling systems, co-operation of neighbouring ranchers in patrolling activities, and ranches being located far from densely populated areas. For the programmes to succeed in the long term, government and conservation agencies will need to give more support to landowners.

\section{Introduction}

Traditionally, conservation efforts have concentrated on protecting plant and animal populations through the establishment of national parks and reserves. These protect only a small proportion of wildlife habitats and, in many countries, increasing their extent is difficult. This is certainly the case in many countries in Latin America, where enforcing wildlife protection laws is also difficult, so that wildlife is often overexploited. It is thus important to evaluate alternative conservation strategies. One such strategy involves the application of wildlife conservation regulations by private range owners on their properties.

While the expansion of the cattle industry has been one of the principal factors in causing deforestation in some parts of Latin America, in seasonally flooded savannahs cattle production has proved to be a relatively non-destructive land-use system, at least compared with alternatives such as rice or sugarcane production. These habitats occur in the llanos (plains) of Venezuela and Colombia, the Beni of Bolivia, the Pantanal of Brazil, other parts of Bolivia, parts of Paraguay and the forested savannahs of Guyana. The establishment of many large ranches throughout this biome has caused minimal habitat modification, and wildlife can be abundant.

In this paper we use examples from ranches in the llanos of Venezuela to evaluate if effective wildlife conservation can coexist with the sustainable use of capybara Hydrochaeris hydrochaeris and caiman Caiman crocodilus, and with cattle production. Because the economic benefits of capybara and caiman harvests can only be realized by conserving wildlife habitats, the harvest of these animals could 
motivate ranchers to protect and/or improve wildlife habitats. If this is the case, owners of large private ranches could be important players in improving wildlife management in Latin America (Shaw, 1991). For example, in Venezuela, where hunting seasons for all wildlife except for duck are long and not rigidly enforced (Brokx, 1984), wildlife harvests are regulated more by land owners than by government organizations. Thus, if government agencies and conservation organizations can work effectively with private land owners it may be possible to make significant conservation advances (Shaw, 1991; Mendez Arocha and Ojasti, 1995). The situation we analyse is not meant to replace efficiently operated and managed national parks, but rather to augment them with a vast amount of privately owned land, where wildlife can coexist with cattle. The incorporation of such ranches into a conservation system may be the only conservation option available to maintain a large portion of llanos biodiversity, particularly in important regions that are not represented in the Venezuelan protected-area system (e.g. the large Cojedes River gallery forests and the huge flooded [esteros] plains of the lower Apure River and Arauca River).

\section{The llanos of Venezuela and their conservation problems}

The llanos of Venezuela are a large low-lying savannah region that contain much of the northern and western regions of the Orinoco River drainage and cover an area of approximately 250,000 sq $\mathrm{km}$. Together with the Colombian llanos $(250,000 \mathrm{sq} \mathrm{km})$, they comprise the largest, uninterrupted area of neotropical savannah north of the equator (Sarmiento, 1984). The llanos are influenced by a well defined wet season from May to November and a dry season from December to April. The extreme seasonality of rainfall, low-lying topography, and relatively impermeable soil combine to cause widespread flooding from June to October. During the extended dry season, aquatic habitats are reduced to small lagoons, pools in seasonal

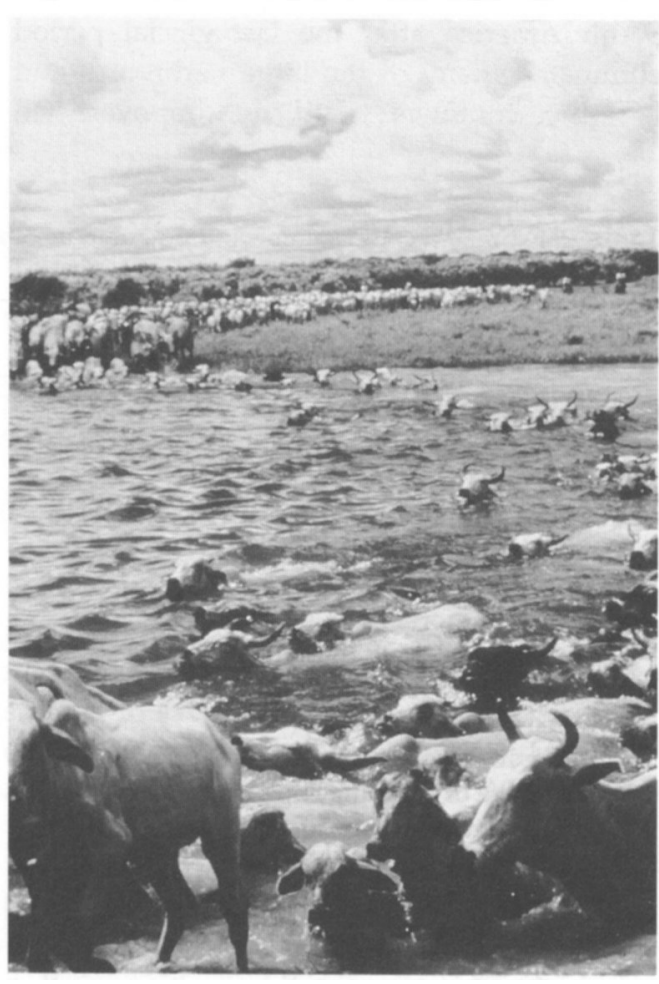

Cattle being herded from flooded lowland sections of a ranch to upland areas. The seasonal patterns of flooding govern much of the activities on the ranches ( $R$. Hoogesteijn)

streams, and rivers. In many areas the reduction of wetland habitats results in extremely dense concentrations of cattle and wildlife around remaining waterholes (Thorbjarnarson, 1991).

Much of the region is occupied by cattle ranches, which are large ( $>1000 \mathrm{ha}$ ) in order to include both uplands and lowlands. Lowlands (particularly in the llano bajo) are typically unsuitable for cattle in the rainy season because they flood, but are needed for pasture in the dry season. Highlands are needed for pasture in the rainy season. There are two national parks in this area, Aguaro-Guariquito (570 sq $\mathrm{km}$ ) and Santos Luzardo (584 sq km), which cover 3.8 per cent of the Venezuelan llanos, but wildlife protection is often poor and wildlife in the parks remains scarce (Hoogesteijn and Mondolfi, 1993).

The massive extinctions that occurred in 
South America after the last glacial period eliminated many of the large herbivores and left the continent with an impoverished ungulate fauna without wild bovids (Ojasti, 1983). The only native grazer that remained was the capybara and this giant rodent is

Table 1. Estimated cattle income and potential income from the sustainable harvest of capybara and caiman for three ranches in the llanos of Venezuela

\begin{tabular}{|c|c|c|c|}
\hline & Ranch A & Ranch B & Ranch C \\
\hline \multicolumn{4}{|l|}{ Cattle population and management } \\
\hline Breeding population (cows and 2-3-yr-old heifers) & 12,000 & 12,000 & 6,000 \\
\hline Average pregnancy $(\%)$ & 53 & 65 & 72 \\
\hline Average age at first pregnancy in heifers $(y \mathbf{r})$ & 3 & 2 & 2 \\
\hline Average calving $(\%)$ & 43 & 58 & 64 \\
\hline Average weaning $(\%)$ & 38 & 53 & 59 \\
\hline Average calf mortality (\%) & 5 & 5 & 5 \\
\hline Average annual adult mortality (\%) & 2 & 2 & 2 \\
\hline Breeding bulls:breeding cows & $1: 22$ & $1: 20$ & $1: 20$ \\
\hline Average adult cow culling (\%) & 15 & 20 & 22 \\
\hline Working life of breeding bulls (yr) & 8 & 5 & 5 \\
\hline Working life of breeding cows (yr) & $10-12$ & 10 & 10 \\
\hline Average annual calf production (weaned/year) & 4,560 & 5,300 & 3,540 \\
\hline \multicolumn{4}{|l|}{ Estimated cattle sales per year (in \$US) } \\
\hline 21662 -yr-old males $\times 229 \mathrm{~kg}$ each $\times \$$ US1.03 $/ \mathrm{kg}$ & 490,816 & & \\
\hline 25182 -yr-old males $\times 250 \mathrm{~kg}$ each $\times \$$ US1.03 $/ \mathrm{kg}$ & & 490,816 & \\
\hline 17702 -yr-old males $\times 280 \mathrm{~kg}$ each $\times \$ U S 1.03 / \mathrm{kg}$ & & & 484,800 \\
\hline 1800 old, culled cows $\times 280 \mathrm{~kg}$ each $\times \$$ USO $92 / \mathrm{kg}$ & 463,680 & & \\
\hline 2000 old, culled cows $\times 320 \mathrm{~kg}$ each $\times \$$ USO $.92 / \mathrm{kg}$ & & 588,800 & \\
\hline 1320 old, culled cows $\times 380 \mathrm{~kg}$ each $\times \$$ USO $92 / \mathrm{kg}$ & & & 461,472 \\
\hline 366 surplus heifers $\times 210 \mathrm{~kg}$ each $\times \$ U S 0.92 / \mathrm{kg}$ & 70,711 & & \\
\hline 518 surplus heifers $\times 240 \mathrm{~kg}$ each $\times \$$ USO.92 $/ \mathrm{kg}$ & & 114,374 & \\
\hline 361 surplus heifers $\times 270 \mathrm{~kg}$ each $\times \$$ US0.92/ kg & & & 89,672 \\
\hline 70 old, culled breeding bulls $\times 500 \mathrm{~kg}$ each $\times \$ U S 1.03 / \mathrm{kg}$ & 36,050 & & \\
\hline 100 old, culled breeding bulls $\times 650 \mathrm{~kg}$ each $\times \$ U S 1.03 / \mathrm{kg}$ & & 66,950 & \\
\hline 60 old, culled breeding bulls $\times 700 \mathrm{~kg}$ each $\times \$ U S 1.03 / \mathrm{kg}$ & & & 43,260 \\
\hline Estimated total income from cattle & $1,061,257$ & $1,418,380$ & $1,709,204$ \\
\hline Cattle income/ha & 7.1 & 23.64 & 12.0 \\
\hline$\%$ income from cattle & 47.9 & 75.4 & 72.6 \\
\hline \multicolumn{4}{|l|}{ Capybara potential income } \\
\hline Total area available for capybara (ha) & 150,000 & 60,000 & 90,000 \\
\hline Ecologically optimum area available (ha) & 112,500 & 45,000 & 36,000 \\
\hline Average density (no./sq km) & 100 & 100 & 100 \\
\hline Population available for harvesting & 112,500 & 45,000 & 36,000 \\
\hline Capybara potentially harvestable ( $30 \%$ a year) & 33,750 & 13,500 & 10,800 \\
\hline Potential income @ \$US30.25/capybara & $1,020,937$ & 408,375 & 326,700 \\
\hline$\%$ income from capybara & 46.1 & 21.7 & 22.0 \\
\hline \multicolumn{4}{|l|}{ Spectacled caiman potential income } \\
\hline Total area available for caiman (ha) & 150,000 & 60,000 & 90,000 \\
\hline Mean density (caiman/ha) & 0.241 & 0.241 & 0.241 \\
\hline Population available for harvesting & 36,150 & 14,460 & 21,690 \\
\hline Caiman potentially harvestable ( $7 \%$ a year) & 2,530 & 1,012 & 1,518 \\
\hline Potential income (hide only) @ \$US53/caiman & 134,090 & 53,636 & 80,454 \\
\hline$\%$ income from caiman & 6.0 & 2.9 & 5.4 \\
\hline
\end{tabular}



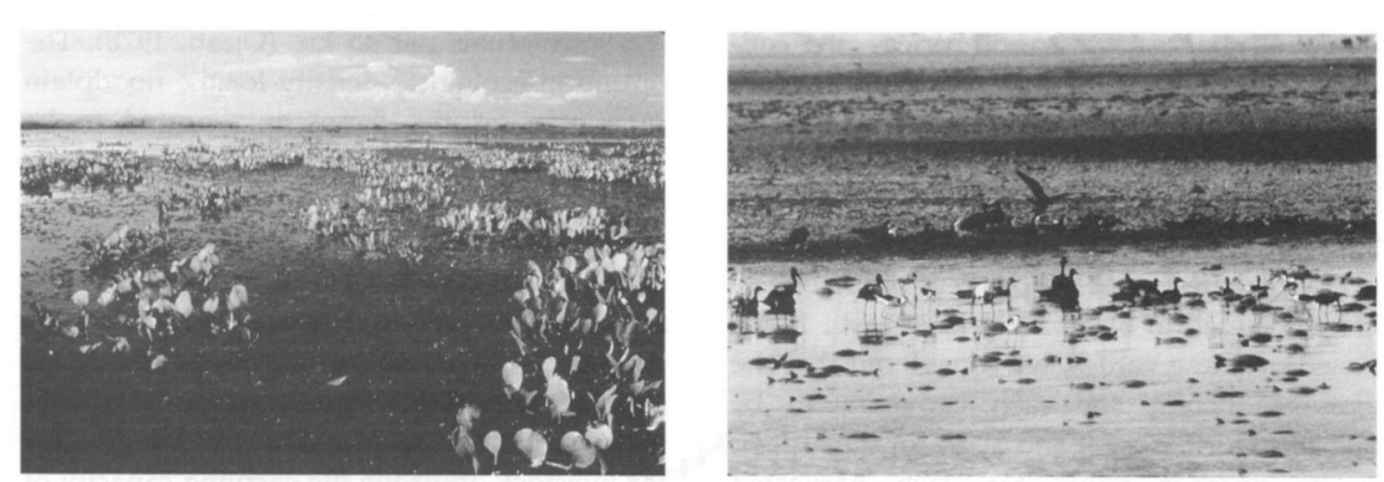

The Venezuelan llanos at the height of the rainy season (left) and in the dry season ( $R$. Hoogesteijn).

restricted to the proximity of rivers and lagoons (Ojasti, 1991). Of the remaining South American ungulates, only deer (white-tailed deer Odocoileus virginianus, pampas deer Ozotocerus bezoarticus, and swamp deer Blastocerus dichotomus) can be regarded as major components of the llanos ecosystem, but they seem unable to maintain population levels high enough to be a major force in ecosystem dynamics (Ojasti, 1983). This natural scarcity of large herbivores has been an important factor permitting cattle to exploit these grasslands.

The region presents several problems for conservation. Because poachers who take wildlife use four-wheel-drive vehicles or horses during the dry season, and motorized boats during the wet season, the large ranches and parks are difficult to patrol. There is little respect for private property and light punishment for offenders (mostly limited to fines and the temporary confiscation of arms). As a result the level of poaching has risen steadily. The problem has been exacerbated by the rising cost of meat from domestic stock (Hoogesteijn and Mondolfi, 1993). Poaching of capybara and caiman often involves not only subsistence hunters but also organized bands hunting for profit. This has resulted in overexploitation of these species in many areas.

One of the region's environmental problems, which threatens to intensify, is the destruction of natural habitats: clearing of semideciduous and gallery forests, and the introduction of exotic grasses in the higher non- flooded areas. Only 6.4 per cent of the mammal species of the Venezuelan llanos are restricted to savannah; most are either partially or completely dependent on forests (Medellin and Redford, 1992).

\section{Data sources}

Data on cattle production were taken from the publications and personal experiences of the first author, who worked as a veterinarian and cattle manager in the area for 9 years and is familiar with the production data and management strategies of the ranches described in this study (Hoogesteijn 1987, 1988, 1989, 1993, 1994; Hoogesteijn et al., 1991; Plasse et al., 1993).

The average income (not profit) derived from cattle production for each ranch was estimated from the existing situation regarding pregnancy, calving, weaning, culling, mortality percentages and average weights (Table 1). Cattle prices used were the actual average prices of cattle in Venezuela (E. Hernandez, pers. comm.), calculated in \$US per $\mathrm{kg}$ of live weight (with a price difference averaged for steers/bulls and cows/heifers for the second half of 1995).

The average income from capybara and caiman harvests was calculated using the density estimates, harvest rates and average prices from previous studies (Ojasti, 1991; Thorbjarnarson, 1991; Espinoza, 1994). We extrapolated these densities and harvest rates to the area of each of the ranches considered. The 
densities, harvest rates and prices are conservative estimates derived from the studied populations, not the optimal levels that could be reached by more effective management or better marketing. An adult harvestable capybara weighing $44 \mathrm{~kg}$ produces an average of $7.5 \mathrm{~kg}$ of salted meat (17 per cent of total body mass), valued at \$US3.5 per kg (Ojasti, 1991). Based on these values, we considered that the average income for each capybara to be \$US26.25 for the meat and \$US4 for the hide.

The average value for each harvested caiman was estimated at \$US10, before 1985, by Rivero-Blanco (1985). Using data published by Espinoza (1994), we calculated the average return for caiman skins from 1988 to 1993 as $\$ U S 47,94,87,56,49$ and 53, respectively. The most recent value (1993) was taken as reference for the calculations of potential caiman income. Espinoza (1994) stated that most caiman meat is used in the ranches for internal consumption, and information on the benefits of its sale were so scarce that he did not include them in his financial analyses. This does not mean that it is not an important resource or that it could not provide additional income if appropriately managed.

\section{Capybara exploitation in the llanos ranches}

The capybara is the largest living rodent and one of the heaviest mammals of South America (adult body mass can reach $59 \mathrm{~kg}$ ). They have a high reproductive rate, with each female producing an average of six young per year (one to two litters per year with three to five young per litter), and attain sexual maturity between 1 and 2 years of age (Chapman, 1991). The availability of water during the dry season limits the amount of habitat suitable for capybara in some areas to 5-30 per cent of the total area. In the wet season capybara habitat expands with the floods (Ojasti, 1973). The capybara is an efficient transformer of grasses into red meat with low fat content. It digests 52 per cent of the total intake of herbage (similar to ruminants), which enable it to attain high population densities of up to
200 individuals per sq $\mathrm{km}$ (Ojasti, 1978). The optimum ecological density for the floodplain savannahs of the llanos is reported to be 100-200 individuals per sq $\mathrm{km}$ for Apure State (Ojasti, 1973, 1978; Herrera, 1986). Other authors, however, report lower densities for capybara in other areas (Eisenberg et al., 1979; Schaller et al., 1984; Alho et al., 1989).

Grazing by cattle, which keeps the grass short and palatable, and the construction of water retention systems to improve rangeland for livestock, improve the carrying capacity of the llanos for the capybara. Its preferred food plants grow in swampy areas not usually frequented by cattle (Gonzalez Jimenez, 1977; Eltringham, 1984). Competition for food can occur between cattle and capybara, but only when there are high densities of both species at the end of the dry season (Gonzalez Jimenez, 1977).

The capybara is hunted by farmers and many Indian communities for its meat. The hide is an important by-product in Venezuela and Colombia, and the principal product of capybara exploitation in Argentina. The skin of the capybara is made into a leather that has the property of stretching in one direction only and is therefore particularly suitable for glove making (Eltringham, 1984). The only large-scale use of its meat occurs in the Venezuelan and Colombian llanos to supply the demand for salted meat, which is eaten in Lent. The Roman Catholic religion does not allow the consumption of meat in this period but does allow its followers to eat fish; the capybara, being aquatic in its habits, is classified by Roman Catholics as fish. The flesh is separated from the skeleton in one piece, salted and air dried. Yearly sustained harvest levels in well-managed cattle ranches with water retention systems and control over poaching can produce a sustained harvest of $1200 \mathrm{~kg} / \mathrm{sq} \mathrm{km} /$ year (density of 100/sq km, harvest rate of 0.30 of the population and an average mass of $40 \mathrm{~kg}$ ). Capybara production can compare favourably with beef cattle production in the llanos (Gonzalez Jimenez, 1977). The limited market for capybara meat, however, diminishes its value and current population densities are typically much lower 
Figure 1. The number of caiman and capybara legally cropped or harvested between 1960 and 1993 in Venezuela.

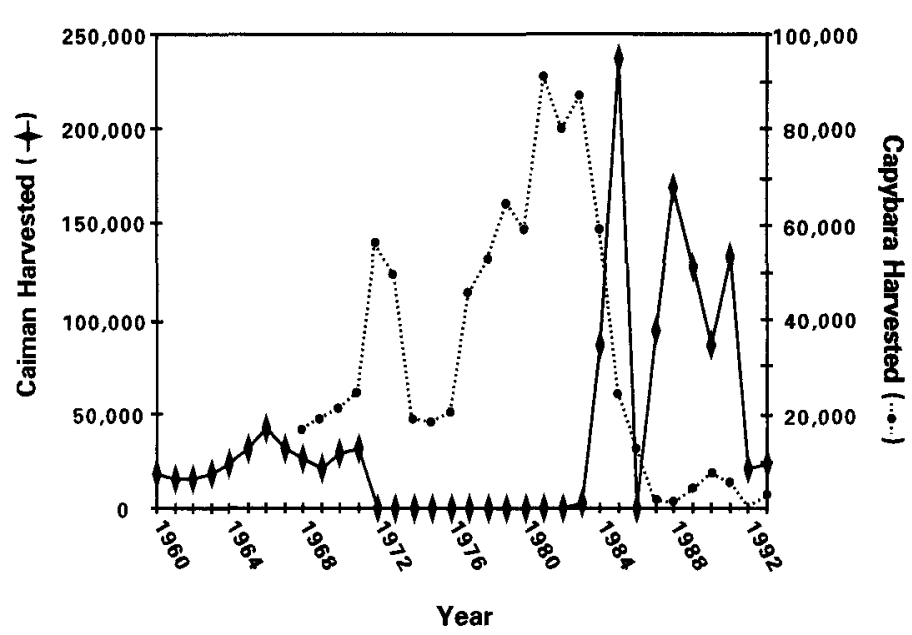

than those which the habitats could support.

There are good records of the harvest of capybara on the privately owned ranches for the last 30 years. Between 1958 and 1962 the government sold a commercial hunting licence to anyone who requested one. Licensed hunters were allowed to hunt anywhere, regardless of ownership and population size. This policy discouraged landowners from protecting capybara and the populations declined. Subsequently, hunting was banned for 5 years. In 1968 hunting was resumed but restricted to owners of ranches with exploitable populations of capybara. The harvest increased slowly, from 17,000 in 1968 to 90,000 in 1981. The number of licences decreased sharply in 1985 because of overoptimistic population estimates and overexploitation (Ojasti, 1991). In 1988 the formula for calculating the harvest quota changed to 20 per cent of the number of capybara actually counted (not estimated). In recent years, increased subsistence and commercial hunting/poaching has reduced capybara populations (Ojasti, 1991; R. Hoogesteijn, pers. obs.). Although the biological information for the management of the capybara is available, it is not being employed. The current level of capybara production is only 3 per cent of what it was in previous years (Figure 1; Luy, 1992).

Between 1975 and 1985 the commercial harvest of capybara on private ranches produced an average of $40,000 \mathrm{~kg}$ of dry salted meat per year and a gross income of $\$$ US0.7 million per ranch (at 1987 exchange rate). This represents only 1.63 per cent of the total value of animal production in Apure State, but capybara were harvested only in 53 ranches, a tiny fraction of the llanos state (Ojasti, 1991).

The llanos experience suggests that sustained harvesting of capybara, in combination with cattle production, is possible and highly profitable. The database on capybara biology and management is extensive and should be more widely applied.

\section{Caiman exploitation in llanos ranches}

The caiman's patterns of movement and habitat use are closely tied to the annual flooding regime of the llanos. As with the capybara, the reduced wetland areas in the llanos in the dry season concentrate caiman; densities reach 50-300 per ha. This results in high mortality by predation and cannibalism on the smaller size classes (Thorbjarnarson, 1991). Also as with capybara, caiman populations can benefit from cattle husbandry: the construction of water retention systems for cattle provides new dry-season habitat for caiman.

The Venezuelan caiman management programme started in 1983 and was based on the harvest of adult males on private lands (Thorbjarnarson, 1991). The history of the caiman harvest between 1960 and 1993 is 
dynamic (Figure 1). Uncontrolled harvests up to the 1960 s reduced caiman populations, and a total ban on exploitation was imposed in 1972. Populations recovered and an experimental harvest was planned based on research by Seijas (1984). In 1984, with a larger number of permit applications, population estimates were derived by calculating an average density for several water bodies on each ranch and using topographic maps to estimate the amount of aquatic habitat per ranch. In 1985, with an even larger number of applications, 0.25-ha sections of each body of water were repeatedly censused and the maximum number of caiman present was used as the best estimate. Much of the censusing was done during the day, when most caiman tend to be hidden, and a correction factor was employed to estimate the total population for each ranch (Seijas, 1984). The harvest target was 7 per cent of the censused population, which represents 40 per cent of adult males with a snout-vent length $>90 \mathrm{~cm}$.

The number of caiman cropped increased from slightly more than 2000 in 1983 to more than 250,000 in 1985 . In 1986 the commercial harvest was halted to evaluate the programme and caiman populations were censused in 65 ranches. After 1989 a technical report was required to ensure that ranches had exploitable caiman populations and, for the first time, ranches without suitable habitat were identified. From 1987 to 1991 the harvest oscillated between approximately 86,000 and 170,000 caiman, but the official harvest declined to 20,000 in 1992 and 1993. Unfortunately, no extensive follow-up censuses were done, although estimates from three states did not detect significant changes in population densities after the 1984-87 harvests, when more than 300,000 caiman were taken. Based on the conservative nature of the legal harvest, the official programme is not believed to have had a negative impact on wild populations (Thorbjarnarson, 1991). The legal harvest, however, represents only part of the picture and the impact of poaching and uncontrolled harvesting should be evaluated.

Although some specialists consider the Venezuelan caiman harvesting experience to be a success (Thorbjarnarson, 1991), other authors consider it to be a failure (Carvajal, 1989; Rivero Blanco, 1990; Luy, 1992). The latter group pointed out a number of deficiencies: permits being given to ranches with dubious ownership papers, unrealistically high harvest estimates, and faults in the control mechanisms. Authors who consider the programme to be a success point out that the harvesting programme has proved to be a method of generating a positive revenue for the users, while making users aware of the necessary relationship between economic benefits and the maintenance of a viable population (Espinoza, 1994). The economic potential of sustainable caiman harvesting on large ranches is considered subsequently, but these arguments illustrate the difficulty involved in effectively managing a programme and clearly demonstrate that the economics of the harvest is only one component of a programme that must be developed to conserve the resource.

\section{Selected cases of llanos ranches with cattle, capybara and caiman exploitation}

Below we focus on three cattle ranches, presenting information on their characteristics, the problems that affect them, the estimated income derived from cattle production (not profit) and potential income from sustainable exploitation of capybara and caiman.

\section{Ranch A}

Ranch A (150,000 ha) has an extensive water retention system in approximately 80 per cent of its area, which provides important dryseason water reservoirs. It has a complete boundary fence and some large fenced paddocks that permit some control of cattle movements. There is a central headquarters and approximately 10 outpost stations. The cattle population of approximately 30,000 suffers high mortality in the dry season and in years with heavy flooding. The ranch uses a traditional production system, with two big cattle round-ups a year, and no organized 
breeding season or systematic vaccination programme (with the exception of foot-andmouth disease).

The ranch has a traditional game cropping system and up to 10,000 capybara were harvested a year during the early 1980s. The income from the capybara harvest paid the annual running costs of the ranch, including the wages of 80 workers and the care of the 30,000 head of cattle (Sunquist, 1984). Recently, the number cropped has declined to 2000-3000 capybara a year. There was also a cropping of 2000 caiman per year.

This ranch had a very efficient patrolling system in the past, controlled by a notorious foreman, but he was shot and killed in 1991 in a rustlers' ambush. His disappearance and the lack of involvement of the owners in vigilance issues has led to an increase in poaching and rustling. The large area of the ranch and its proximity to a squatter group and two towns predisposes it to poaching.

The ranch has a relatively small cattle herd for its size, and cattle production is low. Capybara and caiman could constitute more than 50 per cent of the gross income and double the income per hectare received from cattle production (Table 1).

\section{Ranch B}

Ranch $B$ is a group of three ranches covering 60,000 ha and is owned by a single company. Less than 10 per cent of the area has pastures that have been made more productive by sowing introduced grasses, and approximately 50 per cent is managed with water retention systems. There is a cattle population of approximately 43,000 . The largest and most extensive ranch has a boundary fence and paddocks for bulls and weaned calves, which allows unrestricted movements of breeding cattle during rainy-dry seasons. It has flood control and excellent savannah with natural pastures. The second ranch is divided into smaller paddocks and the cattle herds are moved to low-lying areas in the dry season and to higher ground in the rainy season. The third ranch is at a lower elevation and experiences extensive flooding; it is used only in the dry season for weaned calves, young steers and females.

Up to 1000 capybara were harvested per year from 1986 to 1990 . In recent years, capybara have been harvested only for workers' consumption and to give to people neighbouring the ranch to improve relations. In 1987 and 1988, 2000 caiman were harvested. Ecotourism is being planned for this ranch, but it requires investment in facilities.

This group of ranches has an effective patrolling system, which costs c. \$US50,000 a year and involves approximately 14 well equipped guards. These ranches are the only ones in the area with significant populations of capybara, caiman, deer, wading birds and freshwater turtles. Large numbers of freshwater fish, capybara and feral hog are used for workers' consumption. The owners do not live on the property but are active in management.

The total yearly production of cattle and the income per ha are much higher than for Ranch A (Table 1). As a result, the potential income from capybara and caiman is relatively lower but could contribute up to \$US7.7 per ha and 25 per cent of the ranch's income.

\section{Ranch C}

Ranch $C$ covers 90,000 ha and has an extensive road system, windmills and artificial lagoons, but few water retention systems. There are approximately 10,000 head of cattle. Stock management is better than the national average but does not reach the standard of that of Ranch B, despite being in an area of savannah with better herbage quality and having a large area of more productive introduced pastures. The herd is high grade and a large part is pure-bred (registered) Zebu Nelore and Brahman under artificial insemination programmes. Reproduction and mortality records are taken, nonproductive females are culled and principal infectious diseases are controlled. Approximately 60 per cent of the ranch consists of gallery, semideciduous forest and forested savannah.

Capybara and caiman were harvested in the 1980 s, but the harvest was stopped to provide a wider prey base for jaguar and puma, in the 
hope that this would decrease large cat predation on cattle. In addition, capybara and caiman were viewed as an attraction to ecotourists. This ranch is a pioneer of ecotourism in the llanos. On average there are approximately 24 tourists visiting the ranch at any one time and this activity produces an income of approximately $\$ U S 350,000$ a year. Although wildlife populations are relatively large in the central part of the ranch, near the boundaries they have been reduced by poaching, particularly those of caiman, capybara, deer and turtles.

Cattle production is high but the size of the herd is small in relation to the ranch's size (Table 1). Not all the savannahs are used and the breeding cattle herd has potential for growth. The possible contribution of capybara and caiman harvesting could reach 27.4 per cent of the overall production (Table 1). While estimating future profit from tourism is difficult, it seems reasonable to speculate that the income from ecotourism may equal or surpass the net profit of harvesting. In addition, because caiman and capybara are the main prey of the two big cat species of this ranch, harvesting could have detrimental effects on the natural prey base and possibly increase the number of cattle killed by jaguar and puma.

\section{Can wildlife conservation coexist with wildlife use and cattle production?}

By harvesting capybara and caiman sustainably, ranches could increase their average income from \$US11.9 per ha for cattle production alone to $\$$ US19.6 per ha, an increase of 61 per cent (Table 1). The potential income from wildlife varies among ranches, from 25 to 52 per cent of the total income (cattle production + potential wildlife income; Table 1). Because the economic benefit of capybara and caiman harvest can be realized only by protecting wildlife habitat, this analysis suggests that large ranches in the llanos can play a major role in wildlife conservation and provide economic gains for those involved. Some common denominators for success in this conservation programme include: owners' commitment to conservation, organization of private patrolling systems to prevent poaching, co-operation of neighbouring ranches in patrolling activities, and remoteness from towns or roads. The analyses suggest that capybara and caiman harvesting that is based on initial scientific data, subsequent post-harvest censuses and effective patrolling, could significantly increase the economic benefits generated by the conservation of wildlife. Ecotourism is also starting to become economically viable in the llanos. Thus, we suggest that cattle ranching in conjunction with ecotourism and/or sustainable harvesting of capybara and caiman is a management strategy that warrrants further consideration as a conservation tool. This system is not meant to replace efficiently operated and managed park systems, but rather to complement them.

The incorporation of cattle ranches into a conservation programme will require that government and conservation agencies assist landowners in developing a system that ensures that application of conservation regulations by landowners on their properties remains profitable. At present there is no structured system of economic, social or legal incentives for ranch owners in Venezuela to take part in conservation activities. As a result, current efforts on ranches are due to a few visionary individuals. For long-term continuity, a formalized ranch/reserve network would have a much better chance for sustainability. Such a network could involve owners enjoying tributary incentives, protection from land speculation and officially acknowledged prestigious status. In addition, efforts must be made to study and regulate prices for caiman skins and for capybara meat and skins, and if possible find a means of promoting this industry (i.e. local tanneries).

The model we present is based on an optimistic view of prices. If prices fall or fluctuate widely, the incentives to co-operate in a ranch/ reserve system will decrease. In addition, the management of harvest quotas must be carried out with extreme care. In the past government management of harvest quotas has been plagued by discretionary and sometimes 

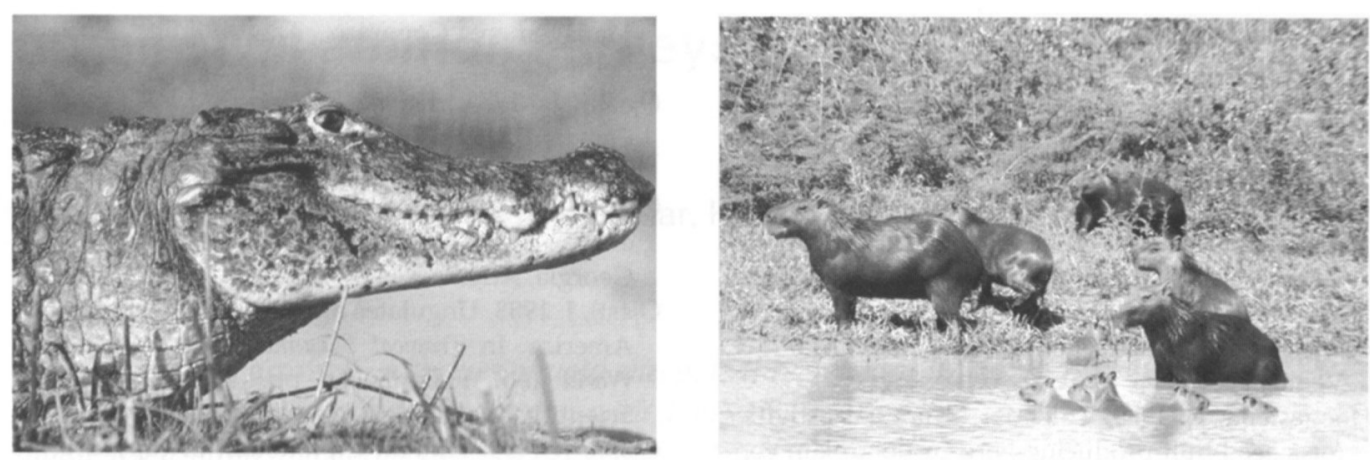

The caiman (left) and the capybara (right) - species for which appropriate management would protect natural habitats and the wildlife associated with these areas.

apparently arbitrary changes in regulations. Such changes make it very difficult for ranch owners to plan for the economic health of their ranches. Finally, because the system we outline is based on economic incentives, there is a need for economic, political and security stability in Venezuela in general and in the llanos in particular. In the past, problems with kidnappings and unrest associated with drug trafficking has had enormous consequences for the Venezuelan cattle industry. Many landowners have been willing to sell their properties at low prices because of fear of unrest.

Because the enlargement and increased surveillance of national park systems is difficult in many countries, the investigation of alternative conservation strategies must be evaluated. The analysis presented here suggests a system that incorporates application of conservation regulations by private land owners on their properties has the potential to make a significant contribution to conservation efforts. This is, however, contingent upon the support of government and conservation agencies.

\section{Acknowledgements}

We would like to thank Jose Ayarzaquena, Lauren Chapman, Fernando Corrales, John Eisenberg, Alejandro Grajal, John Polisar, John Robinson, Andres Seijas, Tom Strushaker and Mel Sunquist for constructive comments on this work. Special thanks are given to the owners and managers of the ranches involved.

\section{References}

Alho, C., Campos, Z. and Goncalves, H. 1989. Ecology, social behaviour and management of the capybara (Hydrochoerus hydrochaeris). In Advances in Neotropical Mammalogy (eds K. H. Redford and J. F. Eisenberg), pp. 163-194. The Sandhill Crane Press, Gainesville.

Brokx, P. 1984. South America. In White-tailed Deer: Ecology and Management (ed. L.K. Halls), pp. 525-546. Stockpole, Harrisburg, PA.

Carvajal, J. 1989. Las babas: bajo la piel del negocio. Paideia, 24, 53-57.

Chapman, C.A. 1991. Reproductive biology of captive capybaras. Journal of Mammalogy, 72, 206-208.

Eltringham, S.K. 1984. Wildlife Resources and Economic Development. John Wiley \& Sons, Ltd, New York.

Eisenberg, J.F. 1980. The density and biomass of tropical mammals. In Conservation Biology: An Evolutionary-Ecological Perspective (eds M. E. Soulé and B. A. Wilcox), pp. 35-55. Sinauer, Sunderland, MA.

Eisenberg, J.F., O'Connell, M.A. and August, P.V. 1979. Density, productivity and distribution of mammals in two Venzuelan habitats. In Vertebrate Ecology in the Northern Neotropics (ed. J.F. Eisenberg), pp. 187-207. Smithsonian Institution Press, Washington, DC.

Espinoza, E.J. 1994. Evaluation of the spectacled caiman (Caiman crocodilus) harvest program in Venezuela's private lands: financial and biological considerations. MA thesis, University of Florida, Gainesville, FL.

Gonzalez-Jimenez, E. 1977. The capybara: an indigenous source of meat in tropical America. World Animal Review, 21, 24-30.

Herrera, E.A. 1986. The behavioral ecology of the capybara, Hydrochoerus hydrochaeris. PhD thesis, Oxford University, Oxford.

Hoogesteijn, R. 1987. Management of strategic 
artificial insemination programmes in Venezuelan beef cattle. In III Beef Cattle Shortcourse (eds D. Plasse and N. Peña), pp. 255-289. Faculty of Veterinary Sciences, Central University, Maracay, Venezuela.

Hoogesteijn, R. 1988. Selection programs for commercial beef cattle herds in the initial stages of development. In IV Beef Cattle Shortcourse (eds D. Plasse and N. Peña), pp. 75-98. Faculty of Veterinary Sciences, Central University, Maracay, Venezuela.

Hoogesteijn, R. 1989. Calendar of annual activities for a seed-bull producing herd in floodplain conditions. In $V$ Beef Cattle Shortcourse (eds D. Plasse and N. Peña), pp. 281-316. Faculty of Veterinary Sciences, Central University, Maracay, Venezuela.

Hoogesteijn, R., Illesca, M. and Mendoza, O. 1991. Program for the improvement of the reproductive efficiency in two extensive beef cattle breeding ranches in the Apure State. Revista Asocebu, 87, 5-21.

Hoogesteijn, R. 1993. Organization and results in an artificial insemination program with non-lactating cows in Apure. In IX Beef Cattle Shortcourse (eds D. Plasse, N. Peña de Borsotti and J. Arango), pp. 131-155. Faculty of Veterinary Sciences, Central University, Maracay, Venezuela.

Hoogesteijn, R. and Mondolfi, E. 1993. The Jaguar. Ediciones Armitano C. A., Caracas, Venezuela.

Hoogesteijn, R. 1994. Management of an artificial insemination program in a non-lactating beef cattle herd and reduction of the loss between pregnancy and calving. Carabobo Pecuario, 128, 10-13.

Luxmoore, R.A., Groombridge, B. and Broad, S. 1988. Significant Trade in Wildlife: A Review of Selected Species in CITES Appendix II. Vol. 2: Reptiles and Invertebrates. IUCN, Gland, Switzerland and Cambridge, UK.

Luy, A. 1992. Consideraciones sobre la factibilidad de establecer un programa de manejo del jaguar mediante la caceria deportiva. In Felinos de Venezuela Biologia, Ecologia y Conservacion (ed. R. Clement), pp. 161-173. Memorias del Symposium organizado por Fudeci. Valencia, Venezuela.

Medellin, R.A. and Redford, K.H. 1992. The role of mammals in neotropical forest-savanna boundaries. In Nature and Dynamics of Forest-Savanna Boundaries (eds P. A. Furley, J. Proctor and J. A. Ratter), pp 159-548. Chapman and Hall, London.

Mendez Arocha, J.L. and Ojasti, J. 1995. Economic and social appraisal of wildlife as a strategy for conservation in tropical America. In Integrating People and Wildlife for a Sustainable Future (eds J. A. Bissonette and P. R. Krausman), pp. 41-43. Proceedings of the First International Wildlife
Management Congress. The Wildlife Society, Bethesda.

Ojasti, J. 1973. Estudio Biologico del Chiguire o Capybara. Fondo Nacional de Investigaciones Agropecuarias, Caracas, Venezuela.

Ojasti, J. 1978. The relation between population and production of the capybara. PhD thesis, University of Georgia, Athens.

Ojasti, J. 1983. Ungulates and large rodents of South America. In Tropical Savannas. Ecosystems of the World (ed. F. Boulière), pp. 427-439. Elsevier Scientific Publishing Company, New York.

Ojasti, J. 1991. Human exploitation of capybara. In Neotropical Wildife Use and Conservation (eds J. G. Robinson and K. H. Redford), pp. 236-252. The University of Chicago Press, Chicago.

Plasse, D., Fossi, H. and Hoogesteijn, R. 1993. Mortality and loss in beef cattle. In IX Beef Cattle Shortcourse (eds D. Plasse, N. Peña de Borsotti and J. Arango), pp. 1-46. Faculty of Veterinary Sciences, Central University, Maracay, Venezuela.

Rivero-Blanco, C. 1990. Hacia Donde Debe ir el Programa Baba? III Taller Sobre Conservacion y Manejo de la Babab (Caiman crocodilus). Relatoria Final. Fundafauna, Caracas.

Sarmiento, G. 1984. The Ecology of Neotropical Savannas. Harvard University Press, Cambridge, MA.

Schaller, G.B., Quigley, H.B. and Crawshaw, P.G. 1984. Biological investigations in the Pantanal, Mato Grosso, Brazil. National Geographic Society Research Reports, 17, 777-792.

Shaw, J. 1991. The outlook for sustainable harvest of wildlife in Latin America. In Neotropical Wildlife Use and Conservation (eds J. G. Robinson and K. $\mathrm{H}$. Redford), pp. 24-34. The University of Chicago Press, Chicago.

Sunquist, F. 1984. Cowboys and capybaras. International Wildlife, 14, 4-9.

Thorbjarnarson, J. 1991. An analysis of the spectacled caiman (Caiman crocodilus) harvest program in Venezuela. In Neotropical Wildife Use and Conservation (eds J.G. Robinson and K. H. Redford), pp. 216-235. The University of Chicago Press, Chicago.

Rafael Hoogesteijn, Department of Wildlife Ecology and Conservation, Newins Ziegler Hall, University of Florida, Gainesville, FL 32611, USA. Current address: Apartado 3083, EI Trigal, Valencia, Venezuela.

Colin A. Chapman, Department of Zoology, 223 Bartram Hall, University of Florida, Gainesville, FL 32611, USA. 